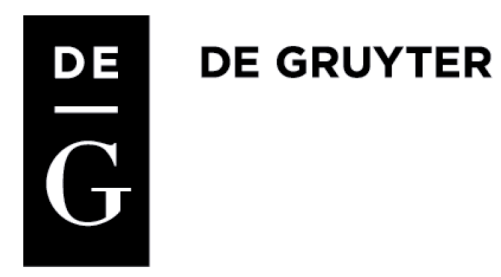

\title{
NEW REALITY - NEW PROBLEMS. FINANCIAL CRIME IN GREATER POLAND IN THE YEARS 1945-1970
}

\begin{abstract}
Systemic transformation in Poland after the Second World War led to deep transformations within the economy. It did not, however, change the way people thought. Despite the chaos of the postwar period, in which all the negative features shaped in the period of occupation manifested themselves, it seemed that the conceptual leaders of the Polish political and economic life would create new quality. However, it soon turned out that old habits die hard and the system created by communists opened a field for many abuses. This was accompanied by a sense of impunity, as the most prominent personalities in a given region were also involved in economic scandals. All this resulted in the creation of "cliques" in which both prominent Party activists and people put by the Party in high positions (usually also members of the Polish United Workers' Party, PUWP) played important roles. On the one hand, after 1956, surveillance by the Security Office (UB) or Security Services (SB) was not that strict anymore, and on the other, the so-called "private initiative" started to develop fast - therefore the more "entrepreneurial" individuals started to exploit the situation and gain wealth. Abusing one's position to organize large-scale thefts was considered relatively normal. This happened in various forms: sometimes directly, but more often by supporting or even organizing private projects with the use of the national, though unsupervised, supply of raw materials or products. This way, the Party members grew richer at the expense of the companies they worked for. This business was relatively widely tolerated by ordinary citizens, who saw it as an excuse to also "organize" goods individually for their own purposes in the companies which employed them. This common belief that "everybody steals" allowed people to justify their own dishonesty. Any attempts to fight this problem failed to produce satisfactory results. The diagnosis, even if correct, had to face reality, in which the pursuit of a better quality of life by the Party elites collided with the officially promoted ascetic lifestyles of the "ideological communists", who, like Wtadystaw Gomutka, did not understood the new times.
\end{abstract}

Keywords: financial crime, Polish People's Republic, society, clique, nomenklatura.

doi:10.1515/sho-2016-0007 


\section{INTRODUCTION}

The end of the Second World War brought about a transformation of the economic system and the emergence of new authorities. They aimed at rebuilding the Polish society and creating an economy without private property, which would respond better to the needs of the society. Ideologically-inclined authorities were supposed to prevent distortions typical, as it was believed, for the free market economy, in which profit was the only driver for all individual activities. The Polish reality turned out to be far from those theoretical assumptions, as the new officials turned out to be quite immune to ideology, but prone to corruption.

The aim of the article is not to analyze all financial crimes committed in Greater Poland. This would be impossible in such a limited space. This text also excludes the most widespread type of crime committed by citizens due to chronic deficits of basic commodities and low living standards - common thefts in the workplace, which aimed at improving the living standard of families. I would, however, like to describe some mechanisms which led to frequent abuses of position in order to gain financial profits, committed by people appointed by the authorities. This problem took various forms in the period discussed, as the circumstances and political rules, and hence, the Polish economy, changed. Taking this into consideration, it is possible to distinguish at least several phases. The first one lasted from the end of the Second World War until the end of the 1940s. In this period, one could see the revival of all past experiences from the period before the war and during the war, which contributed to shaping social attitudes and norms that a normal society would view negatively. This concerned respect for property, especially national property, and a relative tolerance for its appropriation. One must note that the war accelerated and intensified this process, which had in fact been initiated before the war, and enhanced by the political system that amplified large disproportions of living standard between the elites and the rest of society. A new quality emerged with Stalinist policies, when personnel was exchanged on a large scale, also in the economy, as this part of life was subordinated to the decisions of the Party authorities. In this reality, the director was not longer in charge of the company, but was turned into a passive executor of orders received from the "top" and, in a way, just a supervisor. The omnipresent surveillance of the society, combined with omnipotence of the security services, significantly curbed the problem of abuse of position. 
Another contributor was the relatively poor intellectual level of the new personnel, incapable of operating overly complicated swindles. It must be emphasized though that another factor hampering the process was the relative idealism of these people, and their belief that the path they had chosen was right, especially in the initial period. This trend largely weakened in the mid-1950s due to the disappointment and the unfulfilled promises of significant increase in the wealth of the communist society. The clash between those ideas and the often tragic reality showed how failed these promises were. This trend was also intensified by the political "thaw" and the change in policy towards the private sector of the economy, making up for shortages on the market. Despite large fluctuations, this period lasted until the year 1970 .

\section{AN ATTEMPT TO ANALYZE THE SITUATION UNTIL THE YEAR 1950}

In the post-war reality of widespread shortages, the most serious problem that the authorities had to face was preventing illegal transactions and controlling market prices. And the situation was indeed tragic. The Germans, retreating in panic, did not have enough time to take or destroy their food supplies stocked in Poznan. Thus, the abandoned stocks were used to provide food for the residents of Poznan. However, the Soviet war commander of the city took over those warehouses, and allocated only 8 tons of flour and two cows to the residents of Poznan [Jankowiak S., Steffen K. 2001: 57-28]. ${ }^{1}$ To make matters worse, the Red Army looted nearby estates. The tragic condition of supplies, inadequate to the actual needs, was even confirmed by militia reports written for the central authorities in Warsaw. Speculation was common. As the Citizens' Militia Municipal Headquarters reported: "There are more and more people coming from the countryside and other towns to profiteer by selling goods unavailable on the market [APP (Archive of New Files), UWP (Regional Office in Poznań), f. 120; Stryjkowski K. 2013: 331 and the following pages.]. Free market prices were far higher than those set by the authorities.

${ }^{1}$ Compare: The report of captain J. Bardach to the Chief of Propaganda of the Main Political Board of the Polish Army on the situation in Poznan and nearby towns right after the liberation. 
This was even more palpable as the wages were extremely low. For example, a worker earned 2-6 PLN per hour (a teacher - between 400 and 800 PLN a month), while a kilogram of sugar cost 250 PLN, a kilogram of meat - 160 PLN and a kilogram of butter - 400 PLN. Second-hand clothes could cost up to 5,000 PLN. This problem could not be solved without increasing supply. In 1946 a provision was introduced which regulated free market prices, but it proved unsuccessful, and actually led to people hiding their goods on a massive scale and conducting secret transactions - also within national institutions. Honest work was not popular back then, and a large portion of residents engaged in illegal trade, without the necessary permissions [AIPN Warsaw, KG MO (Citizens' Militia Main Headquarters), 35/888]. Crime increased drastically, further encouraged by the weakness of the investigative branches of the Citizens' Militia and the Security Office. Looting was another serious problem, not only in the western lands, but also in Greater Poland and Poznan. The goods were later sold in the free market [Stryjkowski K. 2013: 333]. This activity was facilitated by higher officials of the public administration and even Citizen's Militia and the Security Office officers. They granted formal permissions to appropriate the goods, which made looting technically legal. This is how, for instance, the head of the Regional Security Office in Poznan, major Stefan Antosiewicz, furnished his flat [APP (National Archive in Poznań), KW PPR (Polish Workers' Party Regional Committee), f. 74]. Similar behaviors were also reported among the management of the Polish Workers' Party. A "trusted person", sent from the Regional Committee in Poznan to Szczecin to hold the position of a municipal clerk, committed massive acts of looting and operated two restaurants in the Party premises. This resourceful party member also had a warehouse in Poznan, where he kept the looted goods [APP, KW PPR, f. 6]. The problem was common and the Party authorities were aware of that. As Wiktoria Hetmańska, a Polish Workers' Party activist, said in her speech during the meeting of the Regional National Council (WRN): "The authorities allow for looting and the State Motor Office became a haven for looters" [APP, WRN, f. 17]. There was no mistake there, as those involved in looting did indeed use means of transport owned by the State Motor Transport Company. Fuel for these operations was obtained using a variety of unconventional methods. In Greater Poland, one great scandal was linked to the detection of illegal trade in crude oil in the Head Office for Petroleum Products in Poznań. Many people were involved, including the director of the head office. As a result, 10 culprits were sentenced to labor camps. Several peo- 
ple managed to avoid arrest, as they remained in hiding. The investigation revealed that from autumn 1945 until April 1946, petroleum and crude oil originally allocated for farming purposes appeared in the free market in Greater Poland. The Petroleum Industry Office (CPN) in Poznań was audited to establish the quantities of propellant materials issued to and received by particular farms. The audit proved that significant amounts of petroleum and gasoline were issued based on fake requests. Farm administrators also often received the fuels based on genuine requests and then sold them at higher prices in the free market. Rationing of fuels was based on requests from farm administrators, approved by managers of sowing actions to confirm that a given farm is included in the list, owns tractors, and is therefore authorized to receive the fuel ration. People collecting the petrol were not controlled, though. Furthermore, CPN directors also falsified requests. They bought the requests from administrators, paying 2 PLN per liter. Then, the corrupt managers of sowing actions gave their approval, and a strawperson collected the fuel and sold it on the free market. Several hundred liters of petroleum were found to have been sold this way, but the investigation surely did not reveal the real scale of this problem. Allocations were also sold to the members of the board of the "Rolnik" cooperative in Szamotuły. 260 tons of fuel oil were delivered to the Kórnik Foundation, with an assurance that any amount can be arranged. 17 people were arrested as a result of the scandal, including the inspector of the sowing action in Poznan, members of the "Rolnik" board in Szamotuły and Wronki, the owner of the Surohurt company in Poznań, the deputy head of Kórnik Foundation and the administrator of the Stawiany farm [APP, KSdWzNiSG (Special Commission for Fighting with Fraud and Economic Abuse), f. 117]. This is of course just one example of illegal activities in this field.

The corruption also affected local Party authorities. In 1948, the Party Control Commission took up the case of Bronisław Kowalski, accused of illegal commercial activities. People from the Polish Workers' Party Regional Committee were also involved in this scandal. Kowalski was employed in the "Społem" company as a warehouseman, based on a recommendation from the Party. By accident, he met some people whom he knew from the time of his imprisonment in several German concentration camps. One of these three acquaintances worked as manager in the Regional Security Office stores (the so-called "Konsumy") and another one was a personnel manager in the Wiepofama company. While visiting a "Konsumy" shop, Kowalski noticed clothing materials. When he made a remark that he could 
use a length of the fabric, as he had "no clothing at all", he was offered an exchange - product for product. A cooperator employed in "Społem" offered 150 baby clothing sets in exchange for 6 lengths of good quality fabric; the middleman would receive 2 lengths. Partners had a row, though. The products ordered made it to the Regional Security Office, but the accused did not receive the requested amount of fabric in the right quality in return. The same individuals conducted similar transactions in shoes. These were obtained from "surpluses" owned by drivers delivering shoes to "Społem". Interestingly, 100 pairs of shoes cost 18,000 PLN, while the "refreshments" ordered to celebrate the transaction - 4,000 PLN. Some of the materials stolen this way were obtained from UNRRA deliveries [APP, KSdWzNiSG, f. 117]. In the case of prominent people, even though audits did prove frauds, the guilty parties were spared consequences. In April 1948, an audit was conducted in the Men's and Women's Clothing Factory in Poznan, managed by a PPR activist and, at the same time, a Security Office collaborator. The audit report revealed frauds amounting to nearly 300,000 PLN. However, the request to immediately arrest the manager was not approved by the office. Another audit showed further abuses amounting to over 300,000 PLN. Again, a request was made to arrest the manager. Finally, the case was referred to the Inspection Department in the Ministry of Industry and Trade. This did not, however, result with punishing the culprit - who not only remained free, but even threated the auditors, stating that "they do not know who they are dealing with". Some news even appeared about the planned arrest of the auditor.

"I am in an uncomfortable situation now," wrote the author of the report "as he was the thief, and the fact that I, without regard to his influences, dared to say it openly, may have unpleasant consequences for me. How can you expect honesty then? [APP, KSdWzNiSG, f. 117].

The aforementioned official made appeals to a friend to purge the Party of people of this kind, reasoning that:

[...] small town activists seem to approach this problem differently. (...) you have some influences in the Party, and you approach many things differently, you approach them more idealistically than these Party activists from Poznan (...) I think that discussing this matter in the Poznan branch of the Party will bring no results, and the pressure should come from the top [APP, KSdWzNiSG, f. 117].

The author of the report must have been seriously worried about his future, because in the final part of the private letter, he wrote: 
Regardless of what you do to push this case further, remember this whole affair in case something bad happens to me, which is something I seriously take into consideration, and since you know my luck, I expect I will be punished for innocence here again [APP, KSdWzNiSG, f. 117]. ${ }^{2}$

A separate category of crimes included trading currency, gold and foods sought at the time. One group involved in this type of crime operated in Poznań until 1950. Its members were wokers from the National Rail Company (PKP) who serviced transit trains, which gave them a chance to be in contact with foreigners. They were also allowed to cross the border. Additionally, they were involved in smuggle. They mainly took out meat and pork fat, and brought products lacking in the market: fabrics, needles or buttons. As the authorities established, the smugglers lived in the Górczyn district of Poznań. When preparing an operation, they made inquiries about the arrival of the transit train and then went with the goods to the route of the train. They divided into two groups: one was on the lookout while the other signaled the train driver to slow down. Then, the people with the goods got on the train, and then made deals with the German staff and exchanged the goods. In return for food, they obtained sewing materials and fabrics. The operation was perfectly prepared. Any attempts by Citizens' Militia or the Rail Guards to catch the smugglers failed, as the lookouts immediately signaled any danger, whereupon the people with the goods fled the train and the driver sped up. Smugglers continuously developed their operations: they went to the place where the transit trains stopped, talked to the German staff to find out which products were available, then negotiated the prices, and finalized the transaction in a different place. The description of these people seems interesting:

[...] smugglers and their helpers, fences, are individuals recruited even from the working class, but (...) with an aversion to work, and very often National Rail employees in pursuit of large profits. Customs officers from the "Sanation" period, influenced by the pre-war practices, were accustomed to accepting bribes in exchange for help in smuggle [AIPN Po (Archive of the National Remembrance Institute Poznań) 158/394].

In Poznań, one group selling and buying gold and currencies was broken up. These criminals bought gold from private individuals in unregistered transactions, and then made it into jewelry, later sent to jewelry shops, also without any records. In February 1950, a group of illegal currency traders was broken up. They bought gold and foreign coins (German marks)

2 Ibidem, a letter addressed to Tosiek from April 26, 1948. 
from the railwaymen working on transit trains from Poznan to Germany. Then they took the currency inland (to Eódź) and sold it there with a great profit. Foreign currency was also bought in the countryside, where prices were much lower. The source of the currency were most often parcels from relatives living abroad, particularly in the USA. The problem of currency trade always escalated during the International Poznan Fair events. The Security Office sent their agents to bars and restaurants in the city, particularly the ones most often frequented by foreigners. Gold and currency trade was most intense in Poznań, Kalisz and Konin. In Kalisz, the Security Office even found a German man living in a care home, who had owned a jewelry shop in Kalisz during the war, and sewn a lot of gold and currency into his clothing. Local jewelers bought gold from him. The search brought about the desired effects: the officers detained 11 gold 10-ruble coins, 22 5-ruble coins, several other coins, and 200 grams of gold [AIPN, Po 158/394]. Rigorous investigations and recruitment of agents among smugglers meant that by end of 1950, currency trade significantly decreased. However, the results in terms of counteracting the problem and detecting the culprits were rather poor. As a result of investigations, 237 dollars were detected. In an operation code-named "Stock exchange", 28 people were arrested, who had 2163 dollars and 289 gold coins. This was surely just a fraction of the whole operation. The Security Office divided traders into three groups. The first group included those who bought gold coins as an investment. The second group comprised middlemen, and the third - jewelers and dentists who bought gold because they needed it to run their businesses [AIPN, Po158/394].

The core of this detrimental situation was people's habits, which originated not only from the period of the Second World War. As a prosecutor from the Appeal Court in Poznań wrote:

[...] the long German occupation left a suppurating ulcer in our social body - corruption, speculation and bribery. Antisocial individuals accustomed to easy money made in the days of occupation continue to steal and waste national property. (...) The psychosis of earning easy money by looting or by bribery also affected other individuals among the national and local government officials. (...) Looting, speculation and bribery reached the stage where they make it impossible for the national bodies to function normally [APP, ZM, f. 12].

The action of price and trade control was in full swing in 1946. The socalled "social factor" was included in the controls, but this experiment turned out to be a failure, as these people were easily demoralized. The Delegacy made an appeal to the residents of Greater Poland to write indi- 
vidual complaints and reports. At this stage, the number of denunciations was not yet impressive. Contacts with the representatives of political parties and social organizations were no better, because, according the head of the Committee Delegacy:

[...] they are concerned with their egotistic problems. Cases submitted to the Delegacy show a hint of prejudice and subjectivity [APP, KSdWzNiSG, f. 117].

Speculators' arrests, along with the press coverage, meant that - as a monthly report of the commission noted: "sellers, threatened by regular reports in the press about arresting speculators, did not dare to raise prices". As the Delegacy's head noted:

[...] the arrest of the whole board of the Greater Poland Fishing Cooperative, following information in the press on fish price increases, turned out to be a particularly good preventive measure. The board members were released the next day, after they had pledged to decrease fish prices. (...) However, this step positively influenced price stabilization. During the Christmas season, no price increases were reported in the Poznań region. The operation was successful [APP, KSdWzNiSG, f. 117].

The monetary reform in 1950 was an interesting example of abuse. This operation was being prepared from 1947. In order to conduct it in complete secrecy, the new money was printed in several countries (Czechoslovakia, Hungary, and even Sweden and Switzerland, where coins were minted). The operation was massive: 810 tons of copper and 90 tons of zinc were needed, and ready coins were transported in 248 carriages [AAN, NBP (National Bank of Poland), 7/21; Jankowiak S. 2008: 366]. This was an enormous logistic enterprise, but the introduction of the reform itself turned out to be even more difficult. A large group of people was recruited for this purpose. This was to assure that no violations of law occurred at the time, e.g. in the form of rapid sale of goods. This was due to the fact that the reform was accompanied by the introduction of new regulated prices, sometimes significantly higher than before. The exchange was launched on October 29. Despite the fact that most shops were closed, a sudden increase in shops' takings, especially in the national trade network, was observed. There must have been leaks, then. Of course, officially, rich farmers and the bourgeoisie were blamed. However, indiscriminate purchase of products occurred on a larger scale. Purchases were even made by Citizens' Militia officers and the people involved in the exchange operation. Officials conducting inventory stocks in closed shops took advantage of the unique opportunity to buy products at old prices. Many 
sellers appropriated the goods by hiding them in their flats and making ante-dated sale reports. Inspections at homes revealed stocked alcohol, cigarettes and textiles. Relations were detected between the staff of national and cooperative shops and the so-called:

[...] private initiative - speculators, illegal traders professionally engaged in this business and other exploiters. In many cases shop assistants and managers worked in conspiracy, hiding the appropriated goods in private rooms belonging to the speculators [AAN, NBP, 7/21; Jankowiak S. 2008: 366].

Such abuses emerged in many counties, for example in the Poznań, Kalisz, Konin, Gniezno and Leszno counties.

The problem of benefits in kind and illegal slaughter was a whole separate matter. All possible institutions were involved in the fight against illegal slaughter, including the Delegacy of the Commission for Fighting with Fraud and Economic Abuse, the Citizens' Militia and the Security Office. The so-called "suitcase transport of meat" and illegal trade was targeted [APP, KSdWzNiSG, f. 117]. Deficits in the meat market meant that the authorities paid special attention to this problem. At the end of the year, meat head offices collected stocks of meat in order to deliver them to the market right before Christmas. However, this gave rise to the temptation to exploit this situation and to speculate in meat. Cases of illegal leather processing were also closely investigated, offering evidence of illegal slaughter [APP, KSdWzNiSG, f. 117]. The case grew in importance after the Stalinist policies had been fully introduced. The authorities tried to altogether eliminate the possibility of trading meat. A "battle for breeding" was started due to deficits in the meat market. The operation aimed at organizing purchasing centers so that they were "tight". Butchers were banned from buying livestock, as they were considered speculators who pushed up meat prices. Despite heavier punishments, the scale of illegal slaughter grew. Therefore, even heavier punishments and stricter controls were recommended. The recommendations emphasized that a butcher can only obtain livestock from the cooperative, within the official allocation [APP, KSdWzNiSG, f. 117]. Market deficits led to the situation where speculation also included food and alcohol. Most cases involved small offenses against the act on fighting with inflated prices. 


\section{THE PERIOD AFTER 1956 - A NEW CHAPTER}

The rigorous policies of the late 1940s limited the unfavorable phenomena occurring on the junction of politics and economy. Expansion of the violence apparatus and the massive surveillance of society, combined with the spying obsessions, the constant lookout for "bad intentions of the class enemies and imperialists", and the mass arrests, led to a decrease in criminal activities among top local authorities. The risk was simply too big. Additionally, the state gradually closed down private enterprises and the junction of the national and private economy was where most irregularities appeared. The situation changed after October 1956, when it was officially permitted to run private businesses. Of course, this was not accompanied by any transformation in the functioning of the economy, therefore owners of private companies needed much "resourcefulness" to be able to operate. And this brought about negative consequences. Corruption did not spare the authorities. The most prevalent problem was bribery. It was rife at all levels of the administration, and also concerned the Polish United Workers' Party bodies. Its members, assigned to managerial positions in the economy, acted with impunity, as they were sure of the support from the Party. Cases of abusing professional positions for financial profits were revealed on a larger scale after 1956 [APP, WKKP (Regional Committee of Party Control), 3487], though the problem had been constantly present in Poland. Most often, in the detected cases, the consequences for the accused were not too serious as, owing to the Party support, they frequently remained in their positions. Only extreme cases had different outcomes. This mechanism was common in practice. The position of supervisory institutions in the power structures and their lack of independence meant that, for example, the conclusions of the Supreme Audit Office were only opinions, the execution of which depended on the political will. The employees of this institution were well aware of that fact. Zygmunt Łabędzki talked about it during the meeting of the Regional Committee of Party Control (WKKP), stating that:

The Supreme Audit Office is not capable of fighting crime on its own. Party organizations must deal with those cases 1956 [APP, WKKP (Regional Committee of Party Control), 3487].

And these were prone to local networks influence. Abuses were possible because companies were increasingly run by cliques, comprising the com- 
pany management, including the director, as well as the Party secretary, the head of the workers' council and the head of company council. They had the deciding vote, and the rest of the management, as it was reported during a Party meeting, "only nodded their heads". Jan Brygier, a party activist spoke about it: "'Toe the line' is still the motto. The clique governs, while the masses are just spectators" 1956 [APP, WKKP (Regional Committee of Party Control), 3487]. There was also an awarding mechanism favoring those in power:

[..] services are rendered to the secretary of the Party organization, to the head of the company's council and to the head of the workers' council, who are given financial rewards under any pretext. There are definitely too many receptions with vodka here 1956 [APP, WKKP (Regional Committee of Party Control), 3487].

This system of dependencies meant that auditors were simply afraid to draw conclusions from their audits when the frauds concerned people in high positions. The Party authorities were well aware of that. This was evidenced by opinions voiced during meetings of Party institutions.

Comrades, it is hard to tell the truth openly to people in high positions. Without the help of the Party, the Supreme Audit Office cannot fight crime... Many good comrades joined the fight against crime, but these comrades were persecuted and nobody helped them [APP, WKKP (Regional...), 3487].

Financial crime statistics were also of a rather grim character. The problem was of extreme importance for the whole country, therefore the central authorities initiated the creation, in all counties, of units for fighting with financial crime, speculation and abuse. This did not, however, curb similar crimes. The scale of the problem was indeed large, as in 1957, losses from the detected crimes amounted to 1.5 billion PLN, and in 1958, this increased to 2.1 billion PLN. In the Poznan region, 22 financial crimes in the form of public property theft per 10,000 residents were detected in 1956. In 1957, the rate was almost 27 per 10,000 residents, and in 1958 over 27. Also, the number of suspects and convicts increased (in 1957 128,000 suspects and 65,000 convicts, in 1958 - 127,000 suspects and over 108,000 convicts). Of course, in most cases these were petty thefts committed by regular citizens. Due to the low standard of living, poor wages and difficult living conditions, "stealing to make ends meet" became the norm, and most of these cases remained undetected. The existence of company cliques, which committed frauds and went unpunished, was also a certain 
encouragement to behave this way. Interestingly, many of these crimes were committed by people in managerial positions [Table 1].

Table 1. Crimes committed by managerial staff in the Poznan region in the years 1956-1958

\begin{tabular}{|l|c|c|c|}
\hline \multicolumn{1}{|c|}{ Specification } & 1956 & 1957 & 1958 \\
\hline Directors and managers & 2498 & 1724 & 4559 \\
\hline Accountants and warehousemen & 3554 & 2633 & 5810 \\
\hline Other officials & 6439 & 6677 & 16951 \\
\hline
\end{tabular}

Source: The National Archive in Poznań, WKKP, sign. 3487, the report from the plenary session of the Regional Commission of Party Control in Poznań, June 2, 1959.

In 1960, 28 out of 139 employees found guilty of crimes were directors and deputy directors, 9 were main accountants, and 23 held other managerial positions. Still, this did not result in dismissals on a large scale. In the WZGS company, 12 chairmen and deputy chairmen were convicted for lack of supervision, and they remained in their positions. The data presented are of course underestimated, as they do not include the cases processed by the Citizens' Militia alone, without participation from the Prosecutor's Office. Furthermore, many scandals were not detected at all. According to data from the Prosecutor General's Office, over $20 \%$ of financial crimes were committed by directors and their deputies, over $12 \%$ by department managers, almost $9 \%$ by main accountants, and $10 \%$ by shop managers.

In industry, the most frequent crimes were thefts, usually on a large scale, committed by informal groups (company cliques). Those cases were often hushed up by those involved, as they were capable of falsifying the records. For example, in the Poznan Tobacco Company, tens of thousands of cigarettes were stolen, but the audit showed no deficits. Most often, the crimes were committed on the state-private junction. For example, the Poznan Clothing Company bought wadding from a private supplier and paid for it according to the rates for $100 \%$ quality goods, while only $60-80 \%$ quality goods were delivered. Losses amounted to over 3 million PLN. Owing to that, several employees from the supply department managed to build their own houses. Ordering works from private companies also opened field for abuse. The scale of the problem was massive. Lack of possibility to legally acquire raw materials needed for production remained the basic difficulty for private plants. So, the national plants' man- 
agers resold raw materials and half-finished goods to private businesses. The number of frauds in construction increased sharply after the year 1956. Most frequently this concerned thefts of construction materials, and the people involved were directors, managers and warehousemen. Another category of crimes included cash shortages in trade companies. In 1958, in the Poznan region only, cash shortages in the amount of 2 million PLN were revealed in MHD companies, while in the Communal Cooperatives of Farmers' Self-Help - in the amount of 15 million PLN. And this was of course just the tip of the iceberg. Most commonly this involved bulk purchases from private businessmen, despite the fact that goods acquired this way were more expensive and of worse quality than those from national companies. Price reductions offered a new area of operation for criminals. Underestimating taxes by National Council officials was also common. Another frequent mechanism was using national companies for providing services in the private flats of managerial staff. In order to avoid punishment, those involved tried to win the favor of the Party committee members responsible for making personnel-related decisions. This problem did not decrease over time, despite stricter inspections, which revealed cash and product shortages in half of the companies audited. It was relatively easy to detect deficits in trade companies, but it was much harder in industrial plants, especially the largest ones, where records were falsified at every stage. Overestimating the amount of raw materials and resources used was common. This is how additional amounts of raw materials and finished goods for private trade were obtained [APP, WKKP, 3487].

The most important problem from the point of view of the criminals was providing at least some kind of security in case of detection. This was the main reason why the groups of people involved in and profiting from the thefts expanded. This process took various forms. It was seen as normal that people who were in any way influential in the company belonged to cliques. Therefore, these included not only the director of the company, but also the deputy and, of course, the main accountant, who was responsible for falsifying documents. Usually, the head of the workers' council and the secretary of the Party organization were also involved. However, this circle was usually very small. In more serious cases, more people were included: the head of the local National Council, the Chief of Citizens' Militia, the head of the local Security Office, and a prosecutor. The involvement of these people was supposed to provide complete security for the criminals. Financial profits were also awarded to the uninvolved, but influential people, including the employees of the Party and the national ad- 
ministration (in Party committees or National Councils). An interesting example of "securing" the crime this way was the case of fraud in the Meat Company in Poznan, where the director was dismissed for fraud and replaced with the former secretary of the Regional Committee of the PUWP. As the WKKP report stated:

[...] at first it seemed that this would improve the situation, as for some period he had been somewhat successful in fighting with theft within the Slaughterhouse. However, after some time, the conduct of the comrade began to raise doubts. He ordered his subordinates to prepare parcels with the best meats produced in the Slaughterhouse, and to deliver them to addresses he provided [APP, WKKP, 3487].

Those parcels were delivered not only to the secretary and his family, but also to party activists, including the committees' secretary, and even the first secretary of the Regional Committee of Poznan-Stare Miasto district or the economic secretary of the municipal committee of the PUWP. Some evidence indicates that this list is not exhaustive. Furthermore, the director organized drunken parties at the expense of the company. The "security" system worked well, because when the case was finally investigated by the prosecutor's office, the only person found guilty was the driver delivering parcels, and the case against the director was dropped. Of course, the driver was not completely innocent - encouraged by the behavior of the director, he also stole meat - but the scale of this crime was much smaller. An investigation conducted by WKKP revealed that the secretary of the Party organization in the plant, who also sent parcels, was involved as well. Additionally, the economic secretary of the municipal committee had already been charged for abusing his position for personal benefit, and he did not change his conduct [APP, KW PZPR (PUWP Regional Committee), 3498].

What was also common was providing falsified records concerning the volume of production and then reselling the goods to selected stores - not only private, but also state-owned. In this case, the partners in crime were shop managers, selling the stolen goods. This was the case for example in the Kalisz Silk Company [APP, KW PZPR, 96].

After the year 1956, the authorities noticed a quick increase of adverse phenomena in the economy. As early as June 1957, the PUWP Central Committee told their field offices that there was a need to fight with fraud, corruption, cliques and abuse of positions by Party members. In mid-1957, WKKP in Poznań detected many such cases in several counties of the region. The existence of a number of cliques was also revealed. Their members, as it was stated in the report: 
[...] stole, corrupted, created cliques and, due to the positions they held, claimed priority privileges when purchasing land, ignoring regular citizens who had requested land allocation. This was particularly important with the large and fast-growing demand for land [APP, WKKP, 3497].

Abuse of positions in the Party, administration, or economy, for personal benefits was detected in the following counties: Ostrów, Rawicz, Nowy Tomyśl, Krotoszyn, Gniezno, Czarnków, Jarocin and Poznań. In Ostrów, the clique comprised people in top positions in the executive committee of the municipal National Council. These people took plots away from workers, retirees, and even widows, and assigned them to themselves and their friends. Since the case was revealed and, due to the October transformation, enraged the public, the guilty ones were severely punished: they were dismissed from their positions and ordered to return the appropriated land. They were also expelled from the Party. The culprits must have also used the support of the municipal committee management, as its first secretary was also dismissed even though he had not been charged with anything. A similar scandal was revealed in Gniezno where Party members from the executive committee of the National Council awarded themselves with plots. In the Rawicz area, there was a group comprising seven Party members, which, as it was stated in the report:

[...] drank heavily, committed acts of vandalism under the influence in public places (...) exploiting the positions held for private purposes [APP, WKKP, 3497].

They were members of the PUWP county authorities, including the first secretary and his deputies. The group also comprised the former director of the Rawicz prison, and even the director of the local vocational school. The commission revealed irregularities in national farms in Gniezno county, accusing the directors of frauds in the amount of 100,000 PLN. Bribery was also common. Bribes were usually given by the thieves - for example, employees of the Poznan Grain Plant who sold a carriage of peas illegally. By giving bribes, the criminals protected themselves against possible consequences.

One of the reasons for the spread of financial crime was the large degree of impunity and a certain level of tolerance from the authorities. For many years, the director and the main accountant of the Field Industry Plant in Ostrów committed financial crimes. The case eventually ended up in the prosecutor's office, but it dragged on for many years and was ultimately dropped. A similar case was detected in the Meat Plant in Krotoszyn, but as the WKKP commission established: 
[...] the local prosecutor's office handled this case carelessly due to connections between the head of the prosecutor's office and the director of the plant [APP, WKKP, 3497].

There were many similar cases in large plants in Poznań. Most commonly, these scandals involved directors, deputy directors, and secretaries of plant party organizations. Numerous cases of the kind led the WKKP commission to conclude that "after the $8^{\text {th }}$ plenary session of the Central Committee, a number of members, instead of helping in building socialism in our country, actually aims at destroying it with all means". As WKKP established:

[...] some Party members in responsible positions in economic institutions or state administration create their own private trade outlets and factories [APP, WKKP, 3497].

This was exemplified by the fact that in Jarocin, 11 Party members in managerial positions joined forces with the so-called "private initiative" in order to create a private brick and lime manufacturing company. The following people were involved: the head of the Municipal National Council, the secretary of the executive committee of the Municipal National Council, the managers of the Public Utilities Department and the Department of Industry, the director of a construction materials plant, the director of National Forests Authority, the deputy director of the Polish National Bank, the deputy director of the Construction Materials Field Industry Administration in Poznan, and - from the private sphere - the owner of a 30-hectare farm and the owner of a candy factory. These people even assigned the equipment from the plants they managed to the private company. This problem turned out to be common. A similar case emerged in the Construction Materials Industrial Plant in Kępno. The resourceful group comprised not only the director of the company and the representative of the executive committee of the County National Council, but also the county Chief of Citizens' Militia [APP, WKKP, 3497]. The problem of financial crime kept growing, which the regional Party authorities were aware of. As WKKP assessed:

[...] the scale of financial scandals and thefts, as exemplified by the city of Poznan in the year 1958, increased compared with the year 1957, and it keeps growing [APP, WKKP, 3497].

Therefore, central Party authorities sent a letter to all party cells concerning the units for fighting with abuse and corruption. In this critical assess- 
ment of the results of the fight with corruption and financial crime, it was diagnosed that what lay at its core was liberalism and tolerance on the side of managers, and sometimes even the existence of cliques which made it more difficult to detect crimes. At the central level, the Secretariat created the unit for fighting with fraud and corruption, and the same time advised the establishment of similar units at the regional level. Such units were to comprise: party members working in the prosecutor's office, courts, state inspection offices, Citizens' Militia, the National Hygiene Institute and fiscal control, as well as working class activists from larger plants etc. ${ }^{3}$ Following this step, in July 1958, the Party Unit of the Regional Committee of PUWP sent a letter to lower-level committees, recommending the reorganization of those units at Party committees [APP, WKKP, 3497]. The problem of financial crime was constantly present in Poland in the 1950s and the 1960s. A special plenary session of the regional committee of the PUWP was even organized in order to solve it [APP, KW PZPR, 96]. It remains controversial whether or not the following statements made at the session were true:

Society demands a fierce fight... The working class, farmers, intelligence - they oppose the actions of demoralized individuals, they do not want for their conduct to violate the good name of the whole plant or professional group [APP, KW PZPR, 96].

It seems that society tolerated such conduct of the people in high positions. Of course, anger was expressed, however, the example from above was a certain justification for frauds on a smaller scale, commonly committed by workers.

The Regional Committee plenary session could not put an end to those problems, as no actual analysis of the reality was made. When searching for the reasons of the economic abnormalities, the authorities rejected the theory linking these to the poor living standard of the citizens, despite admitting its importance.

The claim that the morality of workers, salesmen and officials will improve once their wages are higher is a theory presented by our adversaries, enemies of our reality. We are well aware that the improvement of living standards and improvement of the economy is a lengthy process. If we were to accept a different theory, one would have to assume that financial crime must exist for many more years to come as a prob-

${ }^{3}$ On appointing units for fighting fraud and corruption. Instruction of the Secretariat of PUWP Central Committee, November 1957 in: “The Acts of the Polish United Workers' Party Central Committee from the second to the third convent", Warsaw, 1959: 515-518. 
lem related to the economic system. These are views that we must oppose [APP, KW PZPR, 96].

The relatively low punishments and their lack of effectiveness in the fight with abnormalities were also pointed out. It was also quite rightly noted that the severity of punishment alone cannot solve the problem.

One often hears that the increase in financial crime is caused by the allegedly mild punishments. (...) legal provisions alone cannot purge the economy, they will not provide deliveries of goods and will not improve the malfunctioning trade. Provisions and punishments will also not defeat the rule of supply and demand, although they are a vital instrument in the penal and economic policies [APP, KW PZPR, 96].

The flaws in the inspection mechanisms were also pointed out.

Audits, followed by recommendations which no one applied. Still, beautiful reports were written afterwards. The reality is different, and when new auditors come, they say again that this office or this plant is full of flaws, very often bordering on frauds. Then they write more recommendations and reports, and life goes on [APP, KW PZPR, 96].

This diagnosis was an accusation of the authorities, although it was not worded this way.

The perpetrators of all crimes are swindlers, demoralized and unscrupulous individuals. They act in organized criminal groups, they are often educated and put in high positions by the Party or the government, trusted by them and trusted with managing large national wealth. All these people are aware of the detrimental effects of their acts, and they almost always committed crimes when in a good financial situation, when they did not need any financial help. They committed crimes because it was natural to them, and at the same time, they wanted to live comfortable and lavish lives at the expense of millions of honest people [APP, KW PZPR, 96].

The debaters did not understand that, after the period of austerity, the state and Party authorities also wanted to live better lives, and this was impossible just on their salaries. This process was also reinforced by frequent impunity of perpetrators. In the years 1959-1962, the prosecutor's office only referred four cases to the court in the emergency mode, including one financial crime case [APP, KW PZPR, 96]. Even in those cases when confiscation of property was mandatory, it was frequently omitted, and the financial penalties imposed by courts were disproportionate to the losses caused by the financial crime. This was evidenced by court statistics: out of 300 people convicted for causing shortages, 179 received suspended sentences (59\%). This concerned mainly the culprits who caused larger short- 
ages. At the same time, the perpetrators and their families used the illegally obtained wealth in peace. The court cases also tended to be extremely lengthy. For example: in one case against illegal cattle trade, the investigation was launched in June 1958, the indictment was sent to the County Court in Kalisz in October 1958 and after one year, on December 21, 1959, the defendant was acquitted. As a result of an appeal, the prosecutor's office transferred the case to the Court of Review in Kalisz in June 1960. On September 23, 1960, the court overruled the verdict and transferred the case for retrial. In April 1961, the Regional Court in Kalisz sentenced the defendant to 6 months in prison and a 2,000 PLN fine. In December 1961, the case was once again transferred to the Court of Review following an appeal by the defense, and in late January 1962, the court suspended the sentence for 3 years. Even the participants of the Regional Committee plenary session said that:

[...] the criminal policy in the more serious cases, especially economic fraud, even if amended, is still not correct. The financial penalties are still not an adequate instrument of penal repression. Fines are often too low and are disproportionate to the amount of stolen goods and the amount of losses caused by the crime. Serious cases of cash shortages, mismanagement, lack of supervision, are still met with unjustified leniency of the courts, manifested by a relatively large percentage of punishment suspensions and low prison sentences. Although the number of rulings with additional confiscation increased (in 1961, 366 people were convicted, while confiscation was ruled in 16 cases, that is in $4 \%$, and in 1962, 201 people were convicted and confiscation was ruled in 24 cases, that is $10.1 \%$ ) this punishment is still not used frequently enough against the perpetrators of serious social property theft. There are too many arrests imposed to secure the property - instead of fines - very often unjustified by the material gathered in the case file [APP, KW PZPR, 96].

\section{CONCLUSION}

As one can see, the right diagnosis had no impact on the Polish reality throughout the period which is the subject of our interest. The intensifying Party involvement did not improve the situation either. Financial crime, especially on the junction of the private and state sectors, was present in the Polish reality in the whole post-war period, also in Greater Poland. Its causes lay in the core of the socialist system, generating large deficits, and therefore creating a favorable situation for all "resourceful" individuals. Increasing appetites for higher standards of living resulted not only from the natural drive of every individual to improve their lives. They also re- 
sulted from the fact that Poland opened up, to a certain degree, to the outside world, which was a source of consumerist patterns. This concerned not only entrepreneurial individuals in the Polish society, but particularly the state and Party institutions, limited by the model of life imposed first by Stalinism, and then by the first secretary, Władysław Gomułka, who claimed that "the Party authorities should live like the working class" [Eisler J. 2014: 222 et al]. Yet, the Party members had very different expectations and needs, which the social and economic system of the country could not and did not want to satisfy.

\section{BIBLIOGRAPHY:}

\section{ARCHIVE MATERIALS}

Archive of New Files (AAN) - National Bank of Poland (NBP)

National Archive in Poznań (APP) - Komisja Specjalna do Walki z Nadużyciami i Szkodnictwem Gospodarczym (KSdWzNiSzG) [Special Commission for Fighting with Fraud and Economic Abuse]

APP - Komitet Wojewódzki Polskiej Partii Robotniczej (KC PPR) [Regional Committee of the Polish United Workers' Party]

APP - Regional Committee of the Polish United Workers' Party (KW PZPR)

APP - Regional Party Control Commission (WKKP)

APP - Regional National Council (WRN) in Poznań

APP - Regional Office in Poznań (UWP)

APP - Municipal Poznań Management (ZM)

Archive of the Institute of National Remembrance in Warsaw (AIPN Warsaw) - Citizens' Militia Main Headquarters (KG MO)

APP, UWP, sign. 120, Situational report of the Citizens' Militia Municipal Headquarters in Poznań for the period between April 1, 1945 until April 10, 1945.

AIPN Warsaw, KG MO, sign. 35/888, situational report of the Citizens' Militia in Poznań region for the period from 1.05-15.05 1945.

APP, KW PPR, sign. 74, Statement of major S. Antosiewicz of November 15, 1945.

$\mathrm{APP}, \mathrm{KW}$ PPR, sign. 6, Report from the meeting of the executive body of the Regional Committee of the Polish Workers' Party of September 12, 1945.

APP, WRN, sign. 17, Report from the 7th meeting of the Regional National Council of October 5, 1945

APP, KSdWzNiSG, sign. 117, Report on abuses of the Main Office for Petroleum Products and Sowing Action in Poznań, July 24, 1946.

AIPN, sign. Po 158/394, Report of the line of fighting with currency trade and smuggle in the Poznań region for February 1950.

AIPN, sign. Po 158/394, Report of the line of fighting with currency trade and smuggle in the Poznań region for June 1950.

AIPN, sign. Po 158/394, Report of the line of fighting with currency trade and smuggle in the Poznan region for the period between October 1 until December 31, 1950.

APP, ZM Poznań, sign. 12, A letter from the prosecutor of the Court of Appeal in Poznań of August 2, 1945. 
APP, KSdWzNiSG, sign. 117, Ibidem, The report on the activity of the Delegation of the Special Commission in Poznań for December 1946.

APP, KSdWzNiSG, sign. 117, Ibidem, The report on the activity of the Delegation of the Special Commission in Poznan for December 1946.

AAN, NBP, sign. 7/21, A report of the National Bank of Poland for the year 1950.

AAN, NBP, sign. 7/21, A report on the line of fighting with the clerical offences, economic abuse and speculation in the Poznan region for the period from October until December 31, 1950.

APP, KSdWzNiSG, sign. 117, A letter of the head of delegation to the executive bureau of the Special Commission of December 15, 1948.

APP, KSdWzNiSG, sign. 117, A letter to the executive bureau of the Special Commission in Warsaw, November 9, 1948.

APP, KSdWzNiSG, sign. 117, Bulletin no. 52 on fighting with illegal livestock and meat trade, February 12, 1949.

APP, WKKP, sign. 3487, A report from the plenary meeting of WKKP in Poznan of June $2,1959$.

Ibidem, speech of Jan Brygier.

Ibidem, speech of Kazimierz Szymański, manager in the "Malta" Paper Plant,

Ibidem, speech of Michał Rudko, the representative of the regional unit for fighting with abuse and thefts at the Regional Committee.

PP, WKKP, sign. 3487, The report of the plenary session of WKKP in Poznan and the unit for fighting with abuse and corruption at the Regional Committee of PUWP Poznan of January 15, 1960.

APP, KW PZPR, sign. 3498, The report of WKKP in Poznań on implementing the Committee plan and the most important matters settled by WKKP and field commissions of October 15, 1961.

APP, KW PZPR, sign. 96, Shorthand report from the plenary session of the Regional Committee of PUWP in Poznań of January 15, 1964.

APP, WKKP, sign. 3497, A note of WKPB in Poznan on the participation in fighting with speculation, abuse and corruption, September 20, 1957.

APP, WKKP, sign. 3497, A note of WKPB in Poznań on the participation in fighting with speculation, abuse and corruption, September 20, 1957.

APP, WKKP, sign. 3497, The report on the performance of WKKP in Poznan for March 1958.

APP, WKKP, sign. 3497, A note of WKPB in Poznań on the performance of Party units for fighting with abuse, theft and the performance of units at the executive boards of the national councils in the Poznan region, January 31, 1959.

APP, KW PZPR, sign. 96, A shorthand report from the plenary session of the Regional Committee of PUWP in Poznań of January 15, 1964.

Ibidem, speech of Jerzy Zasada.

Ibidem, speech of Czesław Borkowski, deputy regional prosecutor.

Ibidem.

Ibidem, speech of Leszek Lochyński First Secretary of PUWP County Committee in Czarnków.

APP, KW PZPR, sign. 96, On further increase of social engagement in stabilizing the socialist rule of law, order, security and public order, brochure, 1963.

APP, KW PZPR, sign. 96, A shorthand report from the plenary session of the Regional Committee of PUWP in Poznań of January 15, 1964, Ryszard Strzelecki, Secretary of the Central Committee of PUWP. 
LITERATURE

Eisler J. (2014), Siedmiu wspaniatych. Poczet pierwszych sekretarzy KC PZPR [The Magnificent Seven. The First Secretaries of the Polish United Workers' Party Central Committee], Warsaw.

Jankowiak S., Steffen K. [selection and edited] (2001), Województwo poznańskie i szczecińskie [Poznań and Szczecin regions], [in:] Borodziej W., Lemberg H [red.], “Niemcy w Polsce 1945-1950, Wybór dokumentów" [Germans in Poland 1945-1950. Selection of documents], Vol. III, Warsaw.

Jankowiak S. (2008), Wprowadzenie reformy walutowej z 1950 r. w Wielkopolsce [Introduction of the 1950 monetary reform in Greater Poland], [in:] Garbaczewski W., Macyra R. [ed.], "Pieniądz i banki w Wielkopolsce" [Money and banks in Greater Poland], volume 1, Poznań.

Stryjkowski K. (2013), Poznań ‘45. Ostatni rok wojny i pierwszy rok odbudowy [Poznań 1945. The last year of war, the first year of reconstruction], Poznan.

"The Acts of the Polish United Workers' Party Central Committee from the second to the third convent", Warsaw, 1959.

Stanisław Jankowiak - Professor, head of the Modern Polish History Deparment of the Adam Mickiewicz University Institute of History. His research concerns Poland's modern history, particularly political history (fight for power in Poland after the Second World War, the Poznań June, Stalinism, student strikes, the Solidarity movement, systemic transformation after 1989, secret services operation in the Polish People's Republic), issues of national identity (especially the situation of Germans after the Second World War) and relationships between the church and the state. 
